\title{
Concrete and Abstract Racial Domination
}

\author{
JOHN PRESTON \\ Cass School of Education, \\ University of East London, United Kingdom
}

\begin{abstract}
The debate between Mike Cole and David Gillborn which has raged in Power and Education and elsewhere is indicative of a widening schism between Marxism and critical race theory. To describe this debate as orientated around the status of 'race' or 'class' as the central object of social theory, such as in the current debate about the 'white working class' in education, is unhelpful. Rather than see race and class as interdependent systems of concrete domination (where one group, or class, oppress another), this article examines how capitalism brings about an abstract system of domination by race (abstract racial domination). Using the work of Marx, Postone and Du Bois, the article considers that race as capital rather than humanity as racialised labour, is specific to capitalist modes of production. Racialised bodies are already capitalised as 'tertium quid' - a Du Boisian 'third thing' rather than solely as labour or capital. Whites are the 'small masters' of 'sham capital' (whiteness) but are dominated by their own (perceived and socially constructed) phenotype. In terms of praxis, the article argues that critical pedagogies from both critical race and Marxist strands should work towards the abolition of whiteness as a manifestation of capital.
\end{abstract}

\section{Skin Deep}

The white working class are the 'new race victims' (Gillborn, 2009a) and are figures of attraction and repulsion for academics. Academics make distinction through their distance from this pathologised group or by reclaiming their white working-class roots. There were four papers on the white working class at the 2009 British Educational Research Association conference and recent reports by the Runnymede trust and the Department for Children, Schools and Families (DCSF) indicate that the white working class are the exotic failures of the month. There is an academic and policy war machine moving to 'make sense' of the white working class. Critically, dissociated from any real social formation, the term 'white working class' represents a theoretical oxymoron lying between what is seen as privilege (whiteness) and disadvantage (working classness). In unpacking the relationship between whiteness and class, intersectionality is an obvious position that is employed, but rather than diving right into the intersection in an unproblematic way it is more worthwhile to focus on a current academic dispute over 'whiteness' and 'class' (that between Marxists and critical race theorists in education) to interrogate the relationship between these categories. Fundamentally this means moving away from both naturalised and embodied conceptions of 'race' and 'class'. Theoretical struggles over the significance of the white working class and the emphasis which we pay to either 'whiteness' or 'class' have raged over the pages of this journal (Gillborn, 2009b; Cole, 2009a) and elsewhere (Cole \& Maisuria, 2007; Cole 2009b, c, d) and are part of a more widespread theoretical and deepening disjuncture between Marxism and critical race theory (CRT) (Hill, 2009; Mills, 2003).[1] Broadly, CRT and Marxist educational theory (at least for those associated with the 'mini-renaissance' in Marxist educational theory who critique 
CRT - namely Hill, Cole and Maisuria) are on separate trajectories. For some, Marxist critiques will not endanger the development of CRT. Gillborn (2009b) correctly considers that Marxist critiques of CRT are a 'sideshow' but the danger is that this sideshow may actually become a circus in which both sides are caricatured in terms of their position. Although it is may at first appear to be a fair assessment of position, it would be incorrect to caricature critical race theorists as being preoccupied with 'race' and Marxists considered to be preoccupied by 'class'.

As a party who has been identified in Cole's (2009a) 'war of position' with the CRT camp - a positioning that is accurate - in this article I engage with Marxism but from a different direction to Cole, and introduce the category of abstract racial domination as a unique form of racial oppression in capitalism. Rather than an exercise in Marxology, arguing about what Marx really meant, this article takes an alternative reading of Marx to Cole, with a broader interpretation of his theory of capital. I argue that aside from concrete racial domination (what critical race theorists call 'white supremacy' as a world system of multifaceted racial oppression in which white material, psychological and emotional interests are met at the expense of those of people of colour)[2], capitalism produces an insidious form of abstract racial domination (or domination by race as capital). In defining abstract racial domination I synthesise Du Bois and Marx. This involves a metaphorical expansion of Du Bois' conceptual categories on my part. I do not examine in detail Du Bois' notion of a 'world system' of white supremacy as a totalising system of concrete racial domination. Du Bois was explicit about the totalising nature of white supremacy in his use of terms such as 'the veil', for example. 'The veil' does not simply refer to a cognitive/demystification process for people of colour (where they see the world differently to whites, but with insight into the nature of racial oppressions) but an ontological barrier to personhood for people of colour due to the actions of whites. Concrete racial domination is, then, a system of oppression that denies humanity to people of colour, and I do not wish to underplay the violent nature of white supremacy. However, I use Du Bois' conceptual category of 'tertium quid' (third thing) to consider the position of race as capital in what I call abstract racial domination. This is a form of racial oppression specific to capitalism in which race-as-capital acts as a specific form of domination. I start, though, by discussing work on 'white racialisation' in the work of Cole as an entry point for a critique of the current use of the concept of racialisation by Marxists in general.

\section{How Did White People Become White?}

Cole considers that capitalism racialises humans, adopting Miles's definition of racialisation, that racialisation 'accompanies the appropriation of labour power' (2009a, p. 114) through specific 'modes of production' [3], particularly capitalist modalities. Capitalism marks (racialises) bodies in ways that are instrumental to the creation of exchange value, and ultimately profit. However, inconsistent with a view of racialisation through labour power appropriation (which applies to the entire working class), Cole (2009b) primarily considers that racialisation is a category that happens to people of colour and marginalised white groups (for example, Gypsy-Roma-Traveller people and Eastern European immigrants) without explicit consideration of the process of majoritarian white racialisation. Indeed, he refers to 'non-racialised white working class communities' (Cole, 2007, p. 127) and hence considers that there are 'unracialised' whites. In doing so, the so-called unracialised white working 'class' are presented as non-agentic both in terms of the continued acceptance of whiteness (as a political choice) and in any present racist activities. They exist as eternally white. Cole problematically, then, divides the working 'class' into unracialised and racialised fractions. He understands racialisation as a process that is done to 'others' but not to national groups, at least to the majority (in the case of England 'white') ethnic national group. This approach is limited in understanding not only the initial racialisation of the English white working 'class' as 'white' but also in understanding further re-racialisations of that 'class' fraction (Preston, 2007). The white working 'class' were racialised as white at a significant stage in the development of capitalism (Bonnett, 2000). They were agentic in doing so and not just interpellated by capital. Otherwise, as Mills (2003) suggests, white workers can 'have it both ways'. If they act as anti-racists in an industrial struggle then they are class conscious and revolutionary and if they act as racists then they have false consciousness and are reactionary. 
Paradoxically, theories of racialisation, almost by definition, remove race from the sphere of capital in terms of the mode of production. Capitalists may be able to use racialised labour to increase profits but there can not be such a thing as racialised labour power or 'white labour' or any other type of racialised labour in creating exchange value. It therefore makes no sense in terms of labour power to state, as an early manufacturing capitalist does in Roediger's (2009, p. 84) history of race in America, that 'stones hammered by whites cost precisely $\$ 4: 05$ more than those hammered by blacks'. 'Race' only becomes part of labour power where it is used implicitly in the circulation of commodity forms. This only occurs in exceptional cases. For example, in the use of black labour in the Nike store to add value to commodities in terms of 'black authenticity' one might state that 'race' is an explicit part of labour power. Conceptually, then, theories of racialisation in Marxism exclude 'race' from being theorised as a material form of oppression in the same sense as the relation between labour and capital. However, in Cole's (2009a) pointing towards specificities in the capitalist nature of racialisation there are important lessons for CRT, particularly in terms of the location of race at the 'base' of capitalist production (Mills, 2003; Young, 2006). This implies relocating race as being intimately connected with capital. I follow this line and rather than placing 'race' (of which 'whiteness' is part) as a supposedly embodied interpellation of capital I position it as a moment of capital in motion, as part of an abstract system of racial domination.

\section{Beyond Concrete Racial Domination: race as capital}

Marx's critique of capitalism can not be reduced to the exploitation of one 'class' by another (this could be called a C1 and C2 model of 'class' or concrete 'class' domination model) in which racialisation is related to the mode of production. Racial projects in capitalism must be interpreted at a deeper level of abstraction than at the level of concrete (racialised) labour and the materialisation (fetishisation) of capitalist production in a particular time period as employing differently raced humans whose labour power is fundamentally homogeneous. A project that aims to integrate CRT and the Marxist critique of capitalism must place race not only (as Mills and Young suggest) at the 'base' of capitalist production but as a first principle at a high level of abstraction, linking it to the Marxist concept of value and the commodity as the 'cell form' of capitalism. Similarly, concrete racism or white supremacy (where whites oppress people of colour) only grasps part of the story of racial domination under capitalism.[4] Mills considers that liberal contractualism results in an exploitative exchange relation between R1 (whites) and R2 (people of colour) categories of persons, creating the taxonomies of racial exploitation that form the 'material base' of white supremacy (Mills, 2003, p. 188). Like Marxist exploitation, the relations between R1 and R2 are naturalised, but rather than the extraction of surplus value, it is whiteness as property that operates behind the the contract between R1 and R2 (Mills, 2003, p. 191). Mills hence suggests that 'whiteness' can be part of production relations as part of the base of production, but this differs from classical Marxism in terms of considering race to be part of the 'effective power of persons and productive forces' (Mills, 2003, p. 167).

Cole (2009b, p. 21) follows Mills in suggesting that 'race' needs to be considered as part of the base of production and considers that the work of Delgado is a useful corrective to CRT in distinguishing between 'idealist' and 'materialist' wings. The latter is considered to be compared with 'economic' factors (e.g. profit, the labour market, the interests of elite groups) whereas the former is concerned with discourses, words and symbols. Cole considers a 'materialist' orientation of CRT to be most productive in aligning CRT with Marxism. However, his conception of 'materialist' is only one Marxist conception of materialism and crucially a conception that often considers the primacy of concrete (class) rather than abstract (capitalist) domination with regard to race: 'class exploitation and class struggle are constitutive of capitalism and racism' (Cole, 2007, p. 115). Rather than being a system of concrete (class) domination, capitalism represents an objective form of domination rather than the 'many dominating the few' (Postone, 1993, p. 125). It is domination by social labour where 'labour will create alien property and property will create alien labour' (Marx, 1993, p. 238). This is an abstract form of domination rather than a form of market or class domination, being 'the domination of people by abstract, quasi-independent structures of social relations, mediated by commodity determined labour; which Marx tries to grasp with his categories of value and capital' (Postone, 1996, p. 126). Marxist categories of class 
therefore operate at a lower level of abstraction, and capitalism is not a system of class domination but a system of capitalist domination, ultimately domination by social labour. Marx's theory of concrete class groupings in capital is a 'richer, more variegated picture of social groupings and their politics' (p. 315) than a simple two-class model. For example, Marx includes references to the 'middle classes' and the 'dangerous class' (Marx, 1993, p. 360). There are also questions as to whether Marx had developed a complete theory of class rather than a 'first approximation' as to class formation. So although capitalism is fundamentally a class society, the ultimate form of social domination is not class relations; rather 'Labour itself constitutes a social mediation in lieu of overt social relations'. Social domination in capitalism 'cannot be grasped adequately in terms of the overtly social relations between people or groups - including classes' (Postone, 1996, p. 153, emphasis added); without an understanding of capitalism's role in social mediation class is 'an empty phrase' (Marx, 1993, p. 100).

Like concrete class domination where ownership of either capital or labour are significant, concrete racial domination (R1, R2) can mean that race is considered to be ownership rather than phenotype.[5] In theories of white supremacy (of concrete racial domination) whiteness is often considered to be personal 'property' ('whiteness as property' [Harris, 1993] and a 'possessive investment' [Lipsitz, 2006]). From a different conceptual basis, posthumanist or transhumanist (cyborgian) conceptions / critiques of race in which race is a prosthetic [6] also capture something of whiteness as material possession, rather than inherent phenotypical characteristic (Grabham, 2009). In ruling 'class' conceptions of whiteness, race is considered to be both material and prosthetic (Preston, 2007). Race as property is seemingly reproduced through biological processes of human breeding (we implicitly accept that a child's 'race' is derived from their parents) and gains a quasimateriality through biological interpretations of race as a material category. However, in both the 'whiteness as property' and the 'prosthetic whiteness' literature the analysis of 'property' relies upon a pre-capitalist notion of property as a claim to value. Race as property and the racial contract fetishise the nature of race as only being an individual's possession rather than as part of the social relations of production under capitalism - capital in Marx's sense of the term. According to Mills (2003) it requires a conceptual move from property to capital to consider how race might work within capitalism: 'I do think that attempting to incorporate whiteness-as-property into an expanded conception of the relations of production would represent a promising line of research for the necessary transformation of historical materialism' (Mills, 2003, p. 173, emphasis added).

Analogously, the laptop I am writing this on is property and only acquires the status of 'capital' in the capitalist mode of production. Similarly, whiteness as property becomes 'capital' in capitalism as it can act as a surveillance mechanism for capitalists, as a means to discipline other workers through divide and rule, as a way of imposing differential rates of exploitation, to reduce white workers' necessary labour time (by super exploitation of people of colour) and (fundamental to all of these) to establish whiteness as visually salient (Alcoff, 1999). Race has a 'use value' for capitalist production (in the ways described above as part of 'race management' [Roediger, 2009]).

In the longue duree (from the establishment of whiteness, which precedes capitalism, to the present day) of concrete racial domination the specificity of capitalist production brings about a new form of racism - abstract racial domination - which is based upon race as part of the social relations of capitalism as a form of capital rather than as a peculiarity or property of labour (racialisation or a racial project) as in concrete racial domination (the subordination of one racial group by another). I will examine this by, firstly, discussing the notion of abstract domination in the work of Postone.

\section{Marxism and the Limits of 'Class' Analysis in the Work of Marx and Postone}

As the discussion above indicates, the analysis of race as capital is a different form of Marxist analysis to that which considers race to be an epiphenomenon of capitalism. If critical whiteness studies and Marxism are to be engaged conceptually and empirically then it is important to engage 'class' itself not as a social classification but through Marx's conceptual categories. Paradoxically, this means stepping back from 'class', at least initially, as I unfold Marx's abstract categories (Marx, 1993, 2008), which are not about class as the primary relation but rather concern capital as a dynamic property, as 'value in motion'. This leads to an understanding of 'race' which is distinct 
from Marxist theories of racialisation and clarifies CRT understandings of race as property in capitalism. Race emerges both as a concrete category and also as a unique but perpetual moment in the circulation of value.

In Marx's primary economic writings (Capital [2008] and Grundrisse [1993]) race is largely absent from the discussion, but to a greater extent so too are discussions of class as a direct concrete relation. Rather, class antagonisms are concrete manifestations (as discussed above) of the dialectic between labour and capital as material, yet abstract, forces. Postone's (1993) reinterpretation of Marx follows directly from this analysis and questions the perspective of some Marxists that the abstract categories considered by Marx (labour, capital, value) are transhistorical. Rather, the conventional categories of classical political economy (price, profit, rent, wage labour) are the surface categories of Marxist political economy (value, labour power, surplus value) which represent the social universe of capitalism. Postone's theoretical reinterpretation has been considered by Rikowski (2002) to have unsettled the emphasis of Marxism on surface categories of exploitation and concrete domination to reveal the abstract and insidious character of capitalism as a totalising universe of abstract domination. In many ways Postone's analysis of Marx's critical categories is focused on the highest level of abstraction - his discussion of surplus value, exploitation and indeed class is therefore limited. However, for the purposes considered here it represents a fine starting point for the beginning of, if not a full elaboration, of a possible integration of Marxism and CRT. This is not just an academic distinction but has implications in terms of praxis in that the perspective of labour in capitalism is not the standpoint through which capitalism should be critiqued but rather the critique should be based upon the role of labour in capitalism and, for critical race theorists, additionally of whiteness in capitalism. To quote Postone, 'Marxian critique is a critique of labour in capitalism rather than merely a critique of labour's exploitation and mode of social distribution' (Postone, 1993, p. 124).

Postone considers that the commodity as an abstract formation ('the general form of the product only in capitalism' [Postone, 1993, p. 128, emphasis added]) represents the starting point for an analysis of labour in capitalism. The commodity is not to be understood simply as an object, or even a service (although it can appear to be such things): 'The category commodity does not simply refer to an object, but to a historically specific "objective" form of social relations ... a structuring and structural form of social practice that constitutes a radical new form of social interdependence' (Postone, 1993, p. 139). The commodity appears as a good, a use value and 'is a value' (Postone, 1993, p. 127). As a use value the commodity is the employment of concrete labour but 'as a value it is the objectification of abstract human labour' (Postone, 1993, p. 127) which is not biophysical but socially determined (Postone, 1993, p. 145). The exchange of commodities involves an abstraction from both the physical properties of products and (qualitative) differences in types of labour (Postone, 1993, p. 147). Problematically, the concept of the commodity presupposes both free wage labour and capital. According to Postone, in capitalism labour must be doubly free: 'The precondition of such a mode is that labour is free in a double sense; workers must be the free proprietors of their own labour capacity and hence of their own persons: yet they must be free of all objects needed to realize this labour power' (Postone, 1993, p. 270, emphasis added). This implies that the sale of labour as a commodity needs to be unrestricted although, as I will discuss below, 'race' complicates this relation.

This analysis means that we must reconsider concrete relations between classes as being related to capital in the abstract: 'class conflict is a driving force of historical development in capitalism only because it is structured by, and embedded in, the social forms of the commodity and capital' (Postone, 1993, p. 319). This social relation does not represent a separate sphere of human activity (e.g. as the market as opposed to civil society) but a totality, the universe of capital. Capital has its own dynamic, altering the very nature of time from concrete time (dependent on events such as the sun rising) to abstract time: 'uniform, continuous, homogenous empty time [which is] independent of events' (Postone, 1993, p. 202) such as the hours on a clock. The scale of value is dependent upon socially necessary labour time, that is 'the labour time required to produce any use-value under the prevailing socially normal conditions of production and with the prevalent socially average degree of skill and intensity of labour' (Postone, 1993, p. 190). As value is a function of socially necessary labour time an increase in productivity (that increases the number of commodities produced in a unit of time) reduces the socially necessary labour time required to 
produce a unit of that commodity and so reduces the value of that commodity (Postone, 1993, p. 193). This dialectic between value and time creates a treadmill effect whereby 'each new level of productivity once it has become socially generalised not only redetermines the social labour but, in turn, is redetermined by that hour as the "base level"' (Postone, 1993, p. 289). An increase in productivity momentarily increases the value which can be produced in a given period of time but as soon as that increase in productivity is generalised the value that can be produced in a particular unit of time falls to the previous socially determined level. The working hour becomes denser in terms of the productivity of labour whilst simultaneously the value contained in each commodity falls. Rather than being a 'thing' open to rational direction, though, capital has its own dynamic. 'Capital, then is not a thing, or fully grasped in terms of social relations, rather it is a category of movement, of expansion, it is a dynamic category, "value in motion". This social form is alienated, quasi independent, exerts a mode of abstract compulsion and constraint on people and is in motion' (Postone, 1993, p. 269) as self-valorising value. This is an abstract form of social domination. At a lower level of abstraction, capitalists seek to increase profits (or more accurately, surplus value) by increasing labour time expended (the length of the working day), reducing necessary labour time and increasing productivity.

Hence an increase in material wealth may be associated with a fall in value, giving rise to the possibility of a new form of human existence (communism) whilst paradoxically human labour remains necessary to production: 'capital unfolds historically in such as way that the level of productivity becomes less and less dependent on the direct labour of the workers' (Postone, 1993, p. 296). This does not imply that the market form of exchange is the problem: 'abolishing the market mode of co-ordination and value are not identical' (Postone, 1993, p. 291).

Within this analysis of Marx, Postone comments lightly on how this might lead to a reconstruction of Marxist analysis of race. For example, it might lead to a historical approach to 'which activities become recognised socially as labour' (Postone, 1993, pp. 356-357). In terms of my analysis of race below it may also lead to an understanding of which activities can be recognised as capital: in particular, the process by which race is recognised (as a racial project) and then becomes part of abstract racial domination under capitalism. However, Postone's subsequent analysis of racism, although it makes use of concepts of abstract and concrete domination, is orientated around conceptions of ideology and false consciousness. As a case in point, Postone (2003) characterises anti-Semitism in Nazi Germany as being concerned with the National Socialists identifying Jewish people with the abstract character of capitalism whilst identifying Aryans with the concrete character of capitalism. Postone hence considers that racism occurs at the level of ideology in terms of an ideological split between groups considered to represent concrete and those considered to represent abstract racism. This is distinct from his earlier (1993) comments concerning a possibility for the conjoint analysis of 'race' and capitalism, allowing an examination of ways in which certain categories become socially recognised as labour. I take up this strand of Postone's (1993) work in moving to consider how 'race' is fixed to bodies as capital through (violent) labour.

\section{Branding through Labour rather than Racialisation through Ideology}

In Capital (2008) Marx considers that the expenditure of human labour power is obscured both in the process of commodity exchange and in the perceptual process. In the production of a 'coat', for example, 'human labour power must have been actually expended. In this aspect the coat is a depository of value, but though worn to a thread, it does not let this fact show through' (Marx, 2008, p. 26). This process is both 'perceptual and imperceptible by the senses, in the same way the light from an object is perceived by us not as the subjective excitation of the optic nerve, but as the objective form of something outside the eye itself (Marx, 2008, p. 43). If 'race' were a prosthetic and tradable commodity then it could be considered to have similar properties to the coat in Marx's arguments. That is, it would possess the potential for the realisation of exchange value (being the product of human labour) but it would appear to be a perceptual, rather than social, relation. Of course, race has never been traded as an actual prosthetic but in plantation slavery race became a relation that the labourer/enslaved Afrikan [7] carried home with him or her each day for the purposes of identification of that which is labour from that which is capital. In concrete terms, this 
relation could be considered to be part of constant capital ('That part of capital which is represented by the means of production, by the raw material, auxiliary material, and the instruments of labour, does not in the process of production undergo any quantitative alteration of value. I therefore call it the constant part of capital, or more shortly constant capital' [Marx, 2008, p. 139]). Race operated as a commodity in plantation slavery in that labour (violent labour in this case) is required to fix it in place. Plantation slavery is a misnomer for what it really is, being a form of capitalism, as not only the 'instruments' (and Marx concedes that slaves are capital - see Marx, 2008 , pp. 164, 166) but the products of the plantation were produced for exchange in large-scale production with division of labour and with the use of abstract time to measure the production of commodities (Smith, 1997). Slavery is a thoroughly capitalist mode of production, but not from Marx's Eurocentric perspective, and race as capital is built on and around a conscious and revolutionary human subject (Robinson, 2000). Marxists, however, often view plantation slavery through humanist/reformist eyes as morally repugnant and inimical to the immanent mode of capitalist production. The Eurocentric focus of Marx's work and Marxists' moral, rather than political-economic, objections to slavery mean that the locus of capitalism was focused on the factories of Europe rather than plantations ('The term factories was used to describe the West African staging areas gathering labouring bodies for the slave trade' [Roediger, 2009, p. 60]). Marx ultimately takes industrial production and manufacture as the specific example of capitalist production (1993, 2008).

Within slavery, the marking of bodies as raced is 'dead labour', congealed labour (e.g. capital or like traded human hair, a 'zombie commodity' [Berry, 2008]). However, it has the unusual property of infinite extension, meaning where it is marked on a body (the 'branding process') it is extended to all other bodies where property rights are held over humans. This extends past slavery where whiteness becomes a legal form of property within capitalism. This infinite extension is unlike any other form of capital (in classical economic theory) where the formation of that form of capital does not produce non-capitals. Making a hammer for use in a factory does not build 'non-hammers' whereas racialising a body racialises all other bodies. Although this process is explicit in plantation slavery, this 'branding' process extends itself to operate in all capitalist forms of production where race thereby becomes of possible use to the capitalist.

According to Marx, 'Labour in a white skin can not emancipate itself where it is branded in a black skin' (Marx, 1992, p. 414). Although 'branding' in this statement could easily refer to black labour in slavery, I reinterpret it in terms of a process of capitalisation of blackness/whiteness. Whiteness and blackness (or more properly the universe of racial domination which is more nuanced than these binary categories suggest) are mutually constitutive; one presupposes the other. Blackness as capital presupposes whiteness as capital; hence in the 'branding' of labour as black other labour is branded not as black but as white. Moreover, this mutual constitution of race is a form of capital. The process of racial formation operates as a form of semantic nanotechnology where capitalising the skin of one body instantly capitalises all others. The branding of even one body as 'raced' races all other bodies. This branding process (the creation of race as a form of capital) requires the expenditure of human labour (such as punishments, intellectual labour, lynchings and rapes). It was and is achieved through force and violence (Mills, 2003, p. 184). Indeed, it involves the prolonged and continual expenditure, over generations, of congealed labour and force to maintain property rights in whiteness. Racism makes race rather than being its result. However, race is an unusual commodity in that its exchange value can not be separated from the body and raced bodies hence operate as a 'tertium quid'. This term is applied from Du Bois, who states that behind liberal (contractual) conceptions of equality:

lurks the afterthought of force and dominion - the making of brown men to delve when the temptation of beads and red calico clogs. The second thought streaking from the death-ship and the curving river is the thought of the older South - the sincere and passionate belief that somewhere between men and cattle, God created a tertium quid, and called it a Negro - a clownish, simple creature, at times even loveable within its limitations, but strictly foredained to walk within the veil. To be sure behind the thought lurks the afterthought - some of them favouring chance might become men, but in sheer self defence we dare not let them, and we build about them walls so high, and hang between them and the light a veil so 
thick that they shall not even think of breaking through.

(Du Bois, 1996, pp. 74-75, emphasis added)

The tertium quid exists 'somewhere between men and cattle'. In capitalist production this is between labour and capital as the body contains both the capacity to labour and race as capital. I am using Du Bois metaphorically here but Marx is also inconsistent on the subject of slavery, sometimes treating enslaved Afrikans as capital and at other times as instances of unfree labour. However, Marxists concentrate extensively on the concept of 'free labour' as this enables them to make a clear demarcation between what is 'capital' and what is 'labour' in the concrete, but capital and labour are abstract categories in Marx's critical theory which only loosely map onto concrete (observable) social formations. Philosophically, it would be difficult in Marxist analysis to distinguish between the categories of human labourer, sentient robot and cyborg in terms of capital and labour. Animals, in capitalist production, are capital and robots (machinery) can also be considered capital whereas human labourers can be considered to be labour. Sentient robots, as much as they have a 'species being' (consciousness), can be considered to be labour. It is also possible that they can enter production as capital. Cyborgs would certainly possess 'species being' and, again, there is a relation to capital. These examples of hybridity do not contradict Marx's critical theory but rather they are concretisations of Marx's abstract categories of capital and labour. Rather than considering cyborgian futures of humanity, however, the 'tertium quid' of plantation slavery, rather than industrial capital, becomes both the universal form and the first form of the 'capitalisation of humanity' (Rikowski, 2002). As 'raced' (capitalised) beings we have long ago reached Rikowski's dystopia of becoming literally 'human capital'.

Moreover, the process of capitalisation in slavery continues through capitalism with race operating as a form of 'sham property', a form of capital which the capitalist allows the labourer to maintain to reduce the costs of capitalist production. Sham capital [8] is that which is not dispossessed from the labourer as the capitalist 'buys their labour and takes their property first in the form of the product, and soon after that the instrument as well, or he leaves it to them as sham property in order to reduce his own production costs' (Marx, 1993, p. 510). White people therefore are the 'small masters' (Marx, 2008, p. 186) of this sham capital who seemingly 'own' their whiteness. In addition, whites receive an ontological wage [9] which can not be subsumed into categories of labour and is a qualitative rather than quantitative reward for their participation in a system of white supremacy. Note that although its character is qualitative the implications of this qualitative character can indeed be quantitative. Mills (2003, p. 167) considers Du Bois' 'psychological wage of whiteness' to be "'ontological", linked with personhood and arguably more profoundly "material" than the economic. If, as emphasised earlier, personhood is central to the emergence of the modern world, then the reality that has to be faced is that whiteness has historically been a prerequisite for full personhood, recognition as a human being' (Mills, 2003, p. 167). From a Marxist perspective, the economic (capital as value in motion) is the material, and so the habitation of minoritised people as 'tertium quid' is realised in terms of abstract racial domination. The status of tertium quid is one of 'ontological determination by race' as capital (Birt, 1997, p. 208). People of colour are valued for their 'race' as capital as well as their ability to sell labour as a commodity: 'the body parts of the poor are worth more as sources of spare parts than as incarnate persons' (Scheper-Hughes, 1990, cited in Berry, 2008, p. 63). Du Bois' notion of the veil is therefore of ontological and not just perceptual import, as stated in the introduction, in that it demarcates between white supremacist understandings of the human and not human ('tertium quid').

\section{The Abolition of Whiteness}

Distinguishing between concrete and abstract racial domination is not only of theoretical significance but also has importance for critical pedagogy and praxis. At the start of this article I considered that the white working class was a theoretical oxymoron and an object of contestation between Marxists and critical race theorists over claims to oppression. That the white working class has become an object of discussion is not just due to their increased visibility through a reracialisation or a re-objectification by the middle class as 'other' ('not quite white'). The white working class as white gain privilege through their concrete racial domination of other groups and 
(but increasingly to a lesser extent in the workplace) through the value to capital of their whiteness. They are also, though, dominated in an abstract sense by their own whiteness as a form of 'sham' capital, as an object external to them which appears to be, but is not, part of their corporeal being. Race, as a form of 'sham property', 'confronts and rules over labour as a foreign power and stands in an increasingly glaring contrast to the pernicious subjectivity of living labour' (Fracchia, 2008, p. 60). The white worker has a 'possessive investment' in whiteness as property but this property also possesses them as capital. As a Robinsonade [10] worker alone, the individual worker can produce nothing with their whiteness, but massed in the labour process with and against other forms of (racially) capitalised humans the capitalist can mobilise race as capital to increase the intensity of production through 'race management'. This can not just be seen as workers being “"interpellated" by capitalism' (Cole, 2009b, p. 93), but white workers are part of an agentic political class who are property owners (of whiteness) which also possesses them against their corporeality. Returning to the white working class as a concrete class/racial formation, it is possible to understand the anxiety around this group as a dynamic between abstract and concrete racial domination. In terms of concrete racial domination (R1, R2) the white working class maintains privilege whilst in terms of abstract racial domination the use of their 'whiteness' by capital may be on the wane, particularly in a time of economic crisis.

In terms of praxis, problematically, for this group and for all racialised people, Mills (2003) assumes that a non-racial capitalism might be possible and morally preferable to racial capitalism. However, such a conceit is not possible. Whiteness is, in concrete terms, part of a world capitalist system which depends on the labour of people of colour, particularly those in the developing world, for its profits. Moreover, although abolishing whiteness might put an end to concrete racial domination, it could not end the abstract racial domination considered in this article. Critical race theorists should therefore be more explicit in their support for Marxist and anti-capitalist struggles as racial domination is clearly linked to capitalism. Ultimately, then, the abolition of whiteness, in its abstract form, and of capitalism would have to be (following Preston, 2007) conjoint pedagogical and revolutionary projects. The abolition of abstract racial domination can not be achieved without the abolition of capitalism and vice versa. Cole states that 'I do not believe that there will be a Marxist explanation of "white supremacy" ... the concept is incompatible with Marxism' (2009b, p. 35). However, the concept of white supremacy is incompatible with a particular conception of racialisation, that Cole adopts, which is broadly not Marxist but a form of concrete racial domination operating through changes in the regime of (not necessarily capitalist) accumulation. As I have shown in this article, whiteness is an anomaly in an ideal, abstract, model of capitalism but it is one which is part of the dynamic of capital as a form of 'sham' capital in itself. Therefore 'the abolition of whiteness is fundamental to the Marxist educational project as praxis ... [and] the abolition of capitalism and whiteness seem to be fundamentally connected in the current historical circumstances of Western capitalist development' (Preston, 2007, p. 196). Within capitalism whiteness is part of capital, perhaps its weakest link, and anti-capitalist praxis and critical pedagogy should work towards its abolition.

\section{Notes}

[1] This article is intended in the spirit of comradely debate between Marxists and critical race theorists although, as my conclusion shows, the theories need not be as opposed as some might like to believe.

[2] I use the terms 'white' and 'people of colour' in this article to refer not to phenotypical categorisations but as political categories that manifest aspects of power and oppression with regard to 'race'. I use the (American) term 'people of colour' rather than the (English) 'black and minority ethnic' for political reasons as it is a self-defined, rather than a governmental categorisation. Of course, one may dispute the boundaries of these categories (which are subject to political contestation over time) but such 'boundary disputes' are marginal and do not disrupt the oppressive relations between 'whites' and 'people of colour'.

[3] According to Postone (1996, p. 199), 'the mode of production in capitalism should be understood not in terms of technical "forces of production" separate from "relations of production" but in terms of the contradiction between value and material wealth, that is, as a materialised expression of both dimensions of labour in capitalism and, hence, of both the forces and relations of production'. 
[4] The analysis can be expanded to consider differences between forms of concrete and abstract domination such as patriarchy in materialist feminist analysis (Delphy \& Leonard, 1992). Although not a subject of this article, it can be considered that the analysis can be generalised to all materialist theories of oppression and is not limited to class/gender/race such as materialist queer theory, where one group (class) appropriates the product of another group (class).

[5] Phenotype in this context refers to an observable characteristic about an organism which is taken to be a 'trait' of that organism. In theories of racialisation, 'race' is considered to be a (non-biological) trait of the person ('racialised labour').

[6] Prosthetic in this context refers to an external property which is not a phenotypic trait of the individual. 'Race' as prosthetic implies that it is not necessarily an embodied property as a phenotypical property would be.

[7] I use Nehusi's (2004) favouring of 'Afrikan' rather than 'African' in rejecting the Eurocentric use of the term for one which is both politically and linguistically more appropriate.

[8] 'Sham capital' is capital that by itself could not create value but can only do so when combined with other forms of capital. For example, a homeworker might own a machine that is used to create a component for a capitalist enterprise but the enterprise has a sole agreement with the worker for purchase of the component, forbidding the sale by the homeworker on the open market. The homeworker's machine is a form of 'sham capital'.

[9] The concept of an 'ontological wage' relates to Mills's (2003) statement concerning the possession of whiteness which is (due to racial oppression) fundamentally connected to conceptions of personhood and that this is a constant, but unnamed, benefit to whites (hence 'wage') under a system of white supremacy.

[10] 'Robinsonade' here refers to the genre of 'Robinson Crusoe'. A white worker marooned on a desert island would find their whiteness to be singularly unproductive in the production of commodities.

\section{References}

Alcoff, L. (1999) Towards a Phenomenology of Racial Embodiment, Radical Philosophy, 95, 15-26.

Berry, Esther R. (2008) The Zombie Commodity: hair and the politics of its globalization, Postcolonial Studies, 11(1), 63-84. http: / / dx.doi.org/10.1080/13688790801971548

Birt, R. (1997) Existence, Identity and Liberation, in L. Gordon (Ed.) Existence in Black: an anthology of black existentialist philosophy. London: Routledge.

Bonnett, A. (2000) White Identities: an historical and international introduction. London: Longman.

Cole, M. (2007) Marxism and Educational Theory: origins and issues. London: Routledge.

Cole, M. (2009a) The Color Line and the Class Struggle: a Marxist response to critical race theory as it arrives in the UK, Power and Education, 1(1), 111-124. http: / / dx.doi.org/10.2304/ power.2009.1.1.111

Cole, M. (2009b) Critical Race Theory and Education: a Marxist response. London: Palgrave.

Cole, M. (2009c) Critical Race Theory comes to the UK: a Marxist critique, Ethnicities, 9(2), 246-269. http: / / dx.doi.org/10.1177/1468796809103462

Cole, M. (2009d) On 'White Supremacy' and Caricaturing Marx and Marxism: a response to David Gillborn’s 'Who's Afraid of Critical Race Theory in Education', Journal for Critical Education Policy Studies, 7(1). http: / / www.jceps.com/index.php?pageID=article\&articleID $=143$

Cole, M. \& Maisuria, A. (2007) 'Shut the $\mathrm{F}^{\star \star \star}$ Up' 'You have No Rights Here': critical race theory and racialisation in post-7/ 7 racist Britain, Journal for Critical Education Policy Studies, 5(1). http: / / www.jceps.com/index.php?pageID=article\&articleID $=85$

Delphy, C. \& Leonard, D. (1992) Familiar Exploitation: new analysis of marriage in contemporary societies. London: Polity Press.

Du Bois, W.E.B. (1996) The Souls of Black Folk. London: Penguin.

Fracchia, J. (2008) The Capitalist Labour Process and the Body in Pain: the corporeal depths of Marx's concept of immiseration, Historical Materialism, 16, 35-66. http:/ / dx.doi.org/10.1163/156920608X357729

Gillborn, D. (2009a) Education: the numbers game and the myth of white working class underachievement, in K. Sveinsson (Ed.) Who Cares about the White Working Class. London: Runymede. 
Gillborn, D. (2009b) Who's Afraid of Critical Race Theory in Education: a reply to Mike Cole's 'The Color Line and the Class Stuggle', Power and Education, 1(1), 125-131. http: / / dx.doi.org/10.2304/power.2009.1.1.125

Grabham, E. (2009) 'Flagging the Skin': corporeal nationalism and the properties of belonging, Body and Society, 15(1), 63-82. http: / dx.doi.org/10.1177/1357034X08100147

Harris, C. (1993) Whiteness as Property, Harvard Law Review, 106(8), 1709-1795. http: / / dx.doi.org/10.2307/1341787

Hill, D. (2009) Race and Class in Britain: a critique of the statistical basis for critical race theory, Journal for Critical Education and Policy Studies, 7(2). http:/ / www.jceps.com/PDFs / 07-2-01.pdf

Lipsitz, G. (2006) The Possessive Investment in Whiteness: how white people profit from identity politics. Philadelphia: Temple University Press.

Marx, K. (1992) Capital: a critique of political economy, vol. 1. London: Penguin.

Marx, K. (1993) Grundrisse: foundations of the draft of political economy. London: Penguin.

Marx, K. (2008) Capital (a new abridgement). Oxford: Oxford University Press.

Mills, C. (2003) From 'Class' to Race: essays in white Marxism and black radicalism. Lanham: Rowman \& Littlefield.

Nehusi, K. (2004) Who is an Afrikan, African Renaissance, 1(2), 18-23.

Postone, M. (1993) Time, Labour and Social Domination: a reinterpretation of Marx's critical theory. Cambridge: Cambridge University Press.

Postone, M. (2003) The Holocaust and the Trajectory of the Twentieth Century, in M. Postone \& E. Santer (Eds) Catastrophe and Meaning: the Holocaust in the twentieth century. London: University of Chicago Press.

Preston, J. (2007) Whiteness and Class in Education. Dordrecht: Springer.

Rikowski, G. (2002) Education, Capital and the Transhuman, in D. Hill, P. McLaren, M. Cole \& G. Rikowski (Eds) Marxism against Postmodernism in Educational Theory. Lanham: Lexington Books.

Robinson, G. (2000) Black Marxism: the making of the black radical tradition, 2nd edn. Durham, NC: University of North Carolina Press.

Roediger, D. (2009) How Race Survived U.S. History: from settlement and slavery to the Obama phenomenon. London: Verso.

Smith, M. (1997) Mastered by the Clock: time, slavery and freedom in the American South. Durham, NC: University of North Carolina Press.

Young, R. (2006) Putting Materialism Back into Race Theory: towards a transformative understanding of race. http:// redcritique.org/WinterSpring2006/puttingmaterialismbackintoracetheory.htm

JOHN PRESTON is Professor of Education at the University of East London. His interests are in critical race theory, whiteness studies, 'disaster education' and inequalities in lifelong learning. A collection of his work, Whiteness and Class in Education, was published by Springer in 2007. Correspondence: Professor John Preston, Cass School of Education, University of East London, Stratford Campus, Water Lane, London E15 4LZ, United Kingdom (j.j.preston@uel.ac.uk). 